\title{
PENGARUH BUDAYA LOKAL DALAM PRAKTEK AKUNTANSI ORGANISASI PERANGKAT DESA GOBLEG
}

\author{
Luh Asteni Asih, I Made Arya Candra Wardana, Bima Heryanto Gunadi, Ida Ayu \\ Putu Sri Murti Sari, Rina Cahyani, Kd. Trisna Budi Artha Ningsih ${ }^{6}$
}

Jurusan Akuntansi, Universitas Pendidikan Ganesha, Singaraja, Buleleng, Bali

\begin{abstract}
Abstrak
Penelitian ini bertujuan untuk menginvestigasi bagaimana gambaran umum Desa Gobleg, bagaimana organisasi pemerintah desa pada umumnya dan bagaimana praktek akuntansinya, bagaimanakah budaya lokal dapat mempengaruhi praktek organisasi suatu organisasi pemerintahan, apakah yang menjadi tradisi atau budaya di desa gobleg yang berpengaruh terhadap praktek pencatatan Akuntansi serta apakah ada hubungan antara budaya lokal adat Desa Gobleg terhadap praktek akuntansi organisasi pemerintah desa. Pengumpulan data dilakukan dengan menggunakan teknik wawancara dan dokumentasi. Hasil penelitian menunjukkan bahwa praktek akuntansi yang dilakukan masih sederhana yang dilakukan secara manual dilihat dari segi pembukuan penerimaan dana dan pengalokasian dana. Selain itu, terumgkap juga bahwa terdapat pengaruh antara budaya lokal dengan praktek akuntansi organisasi pemerintah desa, dimana untuk menjalankan tugas dan fungsi dibidang adat istiadat, kepala desa memberikan wewenang kepada kepala desa pakraman adat untuk menghimpun dana, melakukan pencatatan atas perolehan dana, pengalokasian dana serta melakukan pelaporan atas penggunaan dana yang berhubungan budaya yang dimiliki sesuai dengan sistem pencatatan yang berterima umum dan mudah dipahami bagi masyarakat pengguna laporan sebagai bentuk pertanggungjawaban atas dana yang dihimpun melalui masyarakat.
\end{abstract}

Kata kunci: budaya lokal; praktek akuntansi; organisasi pemerintahan

\section{Abstract}

This study aims to investigate how the general picture of Gobleg Village, how the village government organization in general and how its accounting practices, how local culture can affect the organizational practices of a government organization, what are the traditions or culture in Gobleg Village that affect the accounting recording practices and whether there is a relationship between the local culture of the Gobleg Village custom and the accounting practices of the village government organization. Data collection was carried out using interview and documentation techniques. The results showed that the accounting practices that were carried out were still simple and that were done manually in terms of accounting for receipt of funds and allocation of funds. In addition, it was also stated that there was an influence between local culture and the accounting practices of village government organizations, where to carry out their duties and functions in customs, the village head gave authority to the customary pakraman village head to collect funds, to record the acquisition of funds, allocation of funds and reporting on the use of funds that are culturally-related funds in accordance with a recording system that is generally accepted and easily understood by the public using the report as a form of accountability for funds collected through the community.

Keywords: local culture; accounting practices; government organization

\section{Pendahuluan}

Desa atau pedesaan dapat diartikan sebagai daerah yang ada di luar kota. Desa merupakan organisasi pemerintahan resmi yang terendah. Berdasarkan undang-undang desa/ UU Desa (UU No. 32 Tahun 2004 dan Peraturan Pemerintah No. 72 Tahun 2005), desa merupakan kesatuan masyarakat hukum yang memiliki batas wilayah yang berwenang untuk mengatur dan mengurus kepentingan masyarakat setempat, berdasarkan asal-usul dan adat istiadat yang berlaku dan dihormati dalam sistem Negara Republik Indonesia. 
Keuangan desa dapat di peroleh dari sumber-sumber pendapatan desa yaitu sebagai berikut:

a. Pendapatan asli desa, seperti hasil usaha desa, pasar desa, hasil gotong royong, dan lain-lain.

b. Bagi hasil pajak daerah kabupaten atau kota dari dana perimbangan keuangan pusat dan daerah.

c. Bantuan keuangan dari pemerintah.

d. Hibah dan sumbangan pihak ketiga yang tidak mengikat.

Menurut Peraturan Pemerintah Republik Indonesia Nomor 17 Tahun 2010 tentang Standar Akuntansi Pemerintahan, Akuntansi adalah proses identifikasi, pencatatan, pengukuran, pengklasifikasian, pengikhtisaran transaksi dan kejadian keuangan, penyajian laporan, serta penginterpretasian atas hasilnya. Halim dan Kusufi (2012) menjelaskan yang dimaksud akuntansi keuangan daerah adalah proses pengidentifikasian, pengukuran, pencatatan, dan pelaporan transaksi ekonomi (keuangan) dari entitas pemerintah daerah (kabupaten, kota, atau provinsi) yang dijadikan sebagai informasi dalam rangka pengambilan keputusan ekonomi oleh pihak-pihak eksternal entitas pemerintah daerah yang memerlukan.

Sistem akuntansi yang dirancang dan dijalankan secara baik akan menjamin dilakukannya prinsip stewardship dan accountability dengan baik pula. Pemerintah atau unit kerja, pemerintah perlu memiliki sistem akuntansi yang tidak hanya berfungsi sebagai alat pengendalian transaksi keuangan, akan tetapi sistem akuntansi tersebut hendaknya mendukung pencapaiaan tujuan organisasi. Menurut Mulyadi (2001), sistem akuntansi adalah organisasi formulir, catatan, dan laporan yang dikoordinasi sedemikian rupa untuk menyediakan informasi keuangan yang dibutuhkan oleh manajemen guna memudahkan pengelolaan perusahaan. Formulir atau dokumen merupakan dokumen yang digunakan untuk merekam terjadinya transaksi. Peraturan Pemerintah Republik Indonesia Nomor 24 Tahun 2005 menjelaskan sistem akuntansi pemerintahan adalah serangkaian prosedur manual maupun yang terkomputerisasi mulai dari pengumpulan data, pencatatan, pengikhtisaran dan pelaporan posisi keuangan dan operasi keuangan pemerintah.

Praktek akuntansi pada suatu organisasi pemerintah tidak hanya dilakukan sesuai dengan peraturan yang ditetapkan oleh pemerintah dalam rangka menciptakan pengelolaan keuangan yang baik, tidak jarang bahwa praktek akuntansi mengikuti kebudayaan yang dijalankan oleh suatu organisasi pemerintah khususnya organisasi perangkat desa. Dilihat dari segi pengertian budaya itu sendiri, budaya merupakan sebuah kebudayaan yang muncul dalam suatu masyarakat yang telah padu dan memiliki satu kesamaan dalam pola pikir dan berkehidupan sosial sehingga mampu menumbuhkan suatu ciri tertentu biasanya berupa kegiatan maupun aktivitas yang dilestarikan dan diagungkan oleh masyarakat. Bagi organisasi perangkat desa yang berada di daerah yang terpelosok atau bahkan organisasi pemerintah desa dengan adat istiadat yang masih kental tidak jarang masih menggunakan metode pembukuan manual dengan sistem pencatatan single entry yang dapat berterima umum bagi masyarakat pengguna laporan keuangan sebagai bentuk pertanggungjawaban atas dana yang diperoleh dari masyarakat melalui berbagai tradisi dalam penghimpunan maupun pengalokasiannya. Desa gobleg merupakan salah satu desa yang merupakan praktek akuntansi dalam salah satu organisasi perangkat desanya dibidang kewenangan dalam pengelola tradisi atau adat istiadat (desa pakraman adat). Berdasarkan hal tersebut maka penulis ingin menjadikan desa gobleg sebagai objek observasi mengenai pengaruh budaya lokal dalam praktek akuntansi disuatu organisasi pemerintah, khususnya organisasi pemerintah desa.

Berdasarkan latar belakang di atas adapun masalah yang dapat dirumuskan yaitu bagaimana gambaran umum Desa Gobleg, bagaimana organisasi pemerintah desa pada umumnya dan bagaimana praktek akuntansinya, bagaimanakah budaya lokal dapat mempengaruhi praktek organisasi suatu organisasi pemerintahan, apakah yang menjadi tradisi atau budaya di desa gobleg yang berpengaruh terhadap praktek pencatatan akuntansiserta apakah ada hubungan antara budaya lokal adat Desa Gobleg terhadap praktek akuntansi organisasi pemerintah desa. 


\section{Hasil dan Pembahasan}

\subsection{Gambaran Umum}

Gobleg adalah sebuah desa di wilayah bali utara tepatnya di Kecamatan Banjar Kabupaten Buleleng. Mungkin tidak banyak orang yang mengetahui desa ini. Tetapi desa ini memiliki segudang keunikan. Desa ini terbagi menjadi empat dusun atau banjar yaitu baanjar tengah, banjar asah, banjar unusan, dan banjar jembong. Letak desa gobleg berbatasan dengan desa lain yaitu desa munduk, desa pedawe, desa kayuputih, dan desa wanagiri. Aktivitas utama dari masyarakat desa gobleg adalah pertanian dan perkebunan, itu dikarenakan memang wilayah desa ini sebagian besar terdiri dari daerah yang memang subur untuk berkebun selain memang berada didataran tinggi. Komoditi utama yang dihasilkan desa gobleg untuk saat ini adalah cengkeh, walaupun tanaman cengkeh adalah komoditas utama desa gobleg namun pada wilayah desa asah juga dihasilkan komoditas lain, seperti bunga kembang seribu dan buah jeruk. Desa ini merupakan desa yang memiliki sejarah yang luar biasa, dan sampai saat ini kehidupan masyarakat juga masih dipengaruhi oleh sejarah. Kehidupan masyarakat masih seperti bentuk kerajaan, hal ini lah yang membedakan desa gobleg dengan desa lainnya. Selain itu ada juga beberapa prasasti yang ditemukan di desa gobleg ini, dan hamper disetiap tahun desa gobleg melaksanakan kegiaatan keagamaan besar dengan waktu yang tidak singkat pula. Atas kebudayaan yang dimiliki oleh setiaap desa, tidak terkecuali desa gobleg pemerintah desa memberikan wewenang khusus kepada lembaga adat desa untuk melaksanakan fungsinya menjalankan kegiatan kemasyarakatan dibidang tradisi, adat dan lain sebagainya yang berhubungan dengan budayaa yang dimiliki masyarakat desa gobleg pada khususnya. Untuk memperkuat wewenangnya lembaga adat diatur dalam Undang-Undang Nomor 6 Tahun 2014 tentaang Desa menempatkan Lembaga Adat Desa sebagai lembaga yang menyeleggarakan fungsi adaat istiadat dan menjadi bagian dari susunan asli desa yang tumbuh dan berkembang atas prakarsa masyarakat desa. Keberadaan Lembaga Adat di desa dalam hal ini tidak otomatis menyebabkan desa berubah status menjadi desa adat. Ketentuan khusus sebagaimana diatur dalam Undang-Undang Desa menjelaskan bahwa Desa Adat harus memenuhi persyaratan sebagai kesatuan masyarakat hukum adat beserta hak tradisionalnya yang secara nyata masih hidup dengan ikatan territorial atau geneologis maupun fungsional. Ini merupakan gambaran umum desa gobleg dimana desa ini merupakan desa yang penulis gunakan sebagai tempat observasi untuk menyelesaikan tugas penelitian ini.

\subsection{Organisasi Pemeritah Desa Secara Umum}

Desa atau pedesaan dapat diartikan sebagai daerah yang ada diluar kota. Desa merupakan organisasi pemerintahaan resmi yang terendah. Berdasrkan Undang-Undang Desa (UU No. 32 Tahun 2004 dan Peraturan Pemerintah No. 72 Tahun 2005), desa merupakan kesatuan masyarakat hukum yang memiliki batas wilayah yang berwenang untuk mengaturdan mengurus kepentingan masyarakat setempat, berdasarkan asal-usul dan adat istiadat yang berlaku dan dihormati dalam system Negara Republik Indonesia. Kewenangan desa Menurut UU Nomor 32 Tahun 2004 tentang Pemerintahan Daerah Pasal 7, yaitu sebagai berikut:

1. Urusan pemerintah yang sudah ada berdasarkan asal-usul desa, misalnya, menetapkan peraturan desa, memilih pemimpin pemerintahan desa, memiliki kekayaan sendiri, menggali dan menetapkan sumber-sumber pendapatan desa.

2. Urusan pemerintahaan yang menjadi kewenangan kabupaten yang diserahkan peraturannya kepada desa.

3. Tugas pembantuan dari pemerintah, pemerintahaan provinsi, dan pemerintahaan kabupaen, serta urusan peraturan dikelola oleh desa tersebut. berikut:

Keuangan desa dapat diperoleh dari sumber-sumber pendapatan desa, yaitu sebagai

1. Pendapatan asli desa, seperti hasil usaha desa, pasar desa, hasil gotong royong, dan lain-lain.

2. Bagi hasil pajak daerah kabupaten atau kota dari dana perimbangan keuangan pusat dan daerah. 
3. Bantuan keuangan dari pemerintah.

4. Hibah dan sumbangan pihak ketiga yang tidak mengikat.

Sumber pendapatan desa yang tidak bisa diambil alih oleh pemerintah atau pemerintahaan daerah, yaitu seperti:

a. Tanah desa

b. Pasar desa

c. Bangunan desa

d. Objek rekreasi yang diurusi oleh desa

e. Pemandian umum yang diurusi oleh desa

f. Hutang desa

g. Perairan, pantai dalam batas tertentu

h. Tempat pemancingan dan pelelangan tetrentu

i. Jalan desa

Struktur pemerintahan desa memiliki struktur seperti dibawah ini:

a. Badan Permusyawaratan Desa (BPD) atau Kepala Desa.

b. Sekretaris Desa dan Kepala Dusun

c. Kaur Pemerintahan, Kaur Pembangunana, Kaur keuangan, Kaur kesra, dan Kaur umum. Lembaga-lembaga pemerintahan desa dapat diuraikan sebagai berikut:

\section{A. Kepala Desa}

Di dalam sebuah desa dipimpin oleh kepala desa. Kepala desa dipilih langsung oleh penduduk desa dari beberapa calon yang memenuhi syarat. Dalam pelantikan kepala desa calon yang memperoleh dukungan suara terbanyak, akan ditetapkan oleh Badan Permusyawaratan Desa (BPD) sebagai kepala desa. Selanjutnya, kepala desa terpilih dilantik oleh bupati atau pejabat lain yang ditunjuk paling lambat 30 hari setelah dinyatakan terpilih. Masa jabatan kepala desa adalah 6 tahun dan dapat dipilih 1 kali lagi untuk masa jabatan berikutnya. Kepala desa dapat digaji dengan tanah kas desa atau yang biasa disebut tanah bengkok. Setelah masa jabatannya habis, tanah itu dikembalikan kepada pemerintahan desa setempat. Dalam Peraturan Pemerintah No. 72 Tahun 2005 tentang Desa pada Pasal 14 Ayat 1 dinyatakan bahwa tugas kepala desa adalah menyelenggarakan urusan pemerintahan, pembangunan, dan kemasyarakataan. Dalam melaksanaakan tugas kepala desa, kepala desa memiliki wewenang dan kewajiban. Wewenang dan kewajiban Kepala Desa diatur dalam Pasal 14 dan 15 Peraturan Pemerintah Nomor 72 Tahun 2005.

B. Perangkat Desa

Perangkat desa bertugas membantu kepala desa dalam melaksanakan tugas dan wewenangnya. Dalam melaksanakan tugasnya, perangkat desa bertanggungjawab kepada kepala desa. Menurut Undang-Undang Nomor 32 Tahun 2004, perangkat desa terdiri dari sekretaris desa (sekdes) dan perangkat desa lainnya yang akan dijelaskan dibawah ini yaitu sebagai berikut:

1. Sekretaris Desa (Sekdes)

Sekretaris desa bertugas dalam bidang administrasi desa, seperti surat-menyurat, membuat laporan desa, dan kegiatan kearsipan. Sekdes adalah seorang Pegawai Negeri Sipil (PNS).

2. Perangkat desa lainnya

Perangkat desa lainnya terdiri dari pelaksanaan teknis lapangan dan unsur kewilayaha.

a. Pelaksana teknis lapangan terdiri dari kepala urusan pemerintahan, kepala urusan pembangunan, kepala urusan umum, kepala urusan keuangan, dan kepala urusan kesejahteraan masyarakat.

b. Unsur kewilayahan merupakan pembantu kepala desa dalam lingkup dusun atau beberapa dusun. Tugasnya meliputi bidang pemerintahan, pembangunan, ketertiban dan keamanan, pembinaan masyarakat, serta melaksanakan peraturan desa di lingkup wilayahnya.

C. Badan Permusyawaran Desa (BPD) 
BPD merupakan wakil dari penduduk desa dalam penyelenggaraan pemerintahan desa. Sebagai wakil rakyat, BPD berkedudukan sejajar dan menjadi mitra kerja pemerintah desa.

D. Lembaga Kemasyarakatan

Ada beberapa lembaga kemasyarakatan di desa yaitu sebagai berikut:

a. Rukun Tetangga (RT). Rukun Tetangga adalah lembaga kemasyarakatan yang dibentuk oleh masyarakat desa yang terdiri dari yang sekurang-kurangnya 20 kepala keluarga dan paling banyak 60 keluarga.

Fungsi Rukun Tetangga:

1. Pengoordinasikan antar warga.

2. Menjembatani hubungan antar sesama anggota masyarakat dengan pemerintah.

3. Pengamanan masalah-masalah kemasyarakatan yang dihadapi warga.

Tugas Rukun Tetangga

1. Melaksanakan kegiatan gotong royong dan kerukunan warga.

2. Melaksanakan peningkatan peran serta masyarakat dalam pemerintahan, pembangunan, dan pembinaan maasyarakat.

3. Membantu terciptanya ketentraman dan ketertiban dalam rangka menunjang stabilitas nasional.

b. Rukun Warga (RW)

Rukun warga dibentuk dari beberapa Rukun Tetangga (RT).

Fungsi Rukun Warga:

1.Pengorganisasian pelaksanaan tugas RT.

2.Pelaksanaan dan menjembatani hubungan antar RT.

Tugas Rukun Warga:

1. Menggerakkan swadaya gotong royong dan partisipasi masyarakat di wilayah.

2. Membantu kelancaran tugas-tugas pokok LKMD dalam bidang pembangunan di desa dan kelurahan.

c. Koperasi Unit Desa (KUD). KUD merupakan lembaga usaha desa yang bergerak dalam bidang ekonomi. Tugas utamanya menyediakan produk kebutuhan desa, pemasaran, dan pendidikan berwirausaha.

d. Pembinaan Kesejahteraan Keluarga (PKK). PKK merupakan lembaga kemasyarakatan yang anggotanya adalah para ibu-ibu rumah tangga.

e. Pos Pelayanan Terpadu (POSYANDU). POSYANDU adalah sistem pelayanan yang di padukan antara satu program dengan program yang lainnya yang merupakan forum komunikasi pelayanan terpadu dan dinamis. Misalnya program KB dengan kesehatan ibu dan anak. Pelayanan yang diberikan posyandu bersifat terpadu. Hal ini bertujuan untuk memberikan kemudahan dan kuuntungan bagi masyaraakat karena di posyandu tersebut masyarakat dapat memperoleh pelayanan lengkap pada waktu dan tempat yang sama.

f. Karang Taruna

Karang taruna adalah lembaga organisasi pemuda yang merupakan wadah tempat menyalurkan potensi pemuda dalam upaya pemberdayaan pemuda untuk mendukung pembangunan dan kemasyarakatan.

Adapun tugas karang taruna yaitu sebagai berikut:

a. Meningkatkan persatuan dan kesatuan pemuda.

b. Membantu pemerintahan desa dalam menyelenggarakan pemerintahaan dan pembangunan .

c. Membantu pemerintahan desa dalam bidang ketentraman dan keamanan

g. Lembaga Pemberdayaan Masyarakat Desa (LPMD). LPMD adalah lembaga kemasyarakatan yang dibentuk warga desa untuk membentuk pemerintahan desa dalam perencanaan dan pelaksanaan pembangunana desa. LPMD memiliki tugas dan fungsi yaitu sebagai berikut:

a. Membantu pemerintahan desa dalam perencanaan dan pelaksanaan pembangunan desa.

b. Meningkatkan peran serta masyarakat dalam pembangunan desa. 
c. Melaksanakan peningkatan pemberdayaan masyarakat.

d. Menampung aspirasi masyarakat desa.

Sistem akuntansi pemerintah desa

Menurut Peraturan Pemerintah Republik Indonesia Nomor 71 Tahun 2010 tentang Standar Akuntansi Pemerintahan, akuntansi adalah suatu proses identifikasi, pencatatan, pengukuran, pengklasifikasian, pengikhtisaran transaksi dan kejadian keuangan, penyajian laporan, serta penginterprestasian atas hasilnya. Halim dan kusufi (2012) menjelaskan yang dimaksud akuntansi keuangan daerah adalah proses pengidentifikasian, pengukuran, pencatatan, dan pelaporan transaksi ekonomi (keuangan) dari entitas pemerintah daerah (kabupaten, kota, atau provinsi) yang dijadikan sebagai informasi dalam rangka pengambilan keputusan ekonomi oleh pihak-pihak eksternal entitas pemerintah daerah yang memerlukan.

System akuntansi yang dirancang dan dijalankan secara baik akan menjamin dilakukannya prinsip stewardship dan accountability dengan baik pula. Pemerintah atau unit kerja pemerintah perlu memiliki sistem akuntansi yang tidak hanya berfungsi sebagai alat pengendalian transaksi keuangan, akan tetapi sistema akuntansi tersebut hendaknya mendukung pencapaian tujan organisasi. Menurut Mulyadi (2001), sistem akuntansi adalah organisasi formulir, catatan, dan laporan yang dikoordinasikan sedemikan rupa untuk menyediakan informasi keuangan yang dibuthkan oleh manajemen guna memudahkan pengelolaan perusahaan. Formulir atau dokumen merupakan dokumen yang digunakan untuk merekam terjadinya transaksi. Peraturan Pemerintah Republik Indonesia Nomor 24 Tahun 2005 menjelaskan sistem akuntansi pemerintahan adalah adalah serangkaian prosedur manual maupun yang terkomputerisasi mulai dari pengumpulan data, pencatatan, pengikhtisaran, dan pelaporan posisi keuangan dan operasi keuangan pemerintah.

\subsection{Budaya Lokal Terhadap Praktek Akuntansi Organisasi Perangkat Desa}

Budaya atau kebudayaan berasal dari bahasa sanskerta yaitu buddhayah, yang merupakan bentuk jamak dari buddhi (budi atau akal) diartikan sebagai hal-hal yang berkaitan dengan budi, dan akal manusia. Dalam bahasa inggris, kebudayaan disebut culture, yang berasal dari kata latin Colore, yaitu mengolah atau mengerjakan. Bisa diartikan juga sebagai mengolah tanah atau bertani. Kata culture juga kadang diterjemahkan sebagai "kultur" dalam bahasa Indonesia.

Budaya adalah suatu cara hidup yang berkembang, dan dimiliki bersama oleh sebuah kelompok orang, dan diwariskan dari generasi ke generasi. Budaya terbentuk dari banyak unsur yang rumit, termasuk sistem agama dan politik, adat istiadat, bahasa, perkakas, pakaian, bangunan, dan karya seni. Bahasa, sebagaimana juga budaya, merupakan bagian tak terpisahkan dari diri manusia sehingga banyak orang cenderung menganggapnya diwariskan secara genetis. Ketika seseorang berusaha berkomunikasi dengan orang-orang yang berbeda budaya, dan menyesuaikan perbedaan-perbedaannya, membuktikan bahwa budaya itu dipelajari. Budaya adalah suatu pola hidup menyeluruh. Budaya bersifat kompleks, abstrak, dan luas. Banyak aspek budaya turut menentukan perilaku komunikatif. Unsur- unsur sosial budaya ini tersebar, dan meliputi banyak kegiatan sosial manusia.

Pengertian budaya lokal dapat dirumuska sebagai bentuk dari nilai-nilai lokal yang terwujud dari hasil pemikiran serta prilaku masyarakat tersebut yang terbentuk secara alami seiring dengan berjalannya waktu. Pada umumnya, ia dapat berwujud sebagai hasil seni, tradisi, hukum adat, ataupun pola pikir. Oleh karena luas wilayah Indonesia yang begitu luas serta memiliki bentuk masyarakat yang benar-benar bervariasi maka terdapat beragam khazanah kekayaan local yang tercantum sebagai kebudayaan lokal.

Budaya lokal merupakan sebuah kebudayaan yang muncul kedalam suatu masyarakat yang telah padu dan memiliki satu kesamaan dalam pola pikir dan berkehidupan sosial sehingga mampu menumbuhkan suatu ciri tertentu biasanya berupa kegiatan maupun aktivitas yang dilestarikan dan diagungkan oleh masyarakat bersuku bangsa tersebut. Indonesia memiliki beragam jenis kebudayaan lokal yang lestari.

Menurut Peraturan Pemerintah Republik Indonesia Nomor 71 Tahun 2010 tentang Standar Akuntansi Pemerintahan, akuntansi adalah proses identifikasi, pencatatan, pengukuran, pengklasifikasian, pengikhtisaran transaksi dan kejadian keuangan, penyajian 
laporan, serta penginterprestasian atas hasilnya. Halim dan Kusufi (2012) menjelaskan yang dimaksud akuntansi keuangan daerah adalah proses pengidentifikasian, pengukuran, pencatatan, dan pelaporan transaksi ekonomi (keuangan) dari entitas pemerintah daerah (kabupaten, kota, atau provinsi) yang dijadikan sebagai informasi dalam rangaka pengambilan keputusan ekonomi oleh pihak-pihak eksternal entitas pemerintah daerah yang memerlukan.

Sistem akuntansi yang dirancang dan dijalankan secara baik akan menjamin dilakukannya prinsip stewardship dan accountability dengan baik pula. Pemerintah atau unit kerja pemerintah perlu memiliki sistem akuntansi yang tidak hanya berfingsi sebagai alat pendalian transaksi keuangan, akan tetapi sistem akuntansi tersebut hendaknya mendukung pencapaian tujuan organisasi. Menurut Mulyani (2001), sistem akuntansi adalah organisasi formulir, catatan, dan laporan yang dikoordinasi sedemikian rupa untuk menyediakan informasi keuangan yang dibutuhkan oleh manajemen guna memudahkan pengelolaan perusahaan. Formulir atau dokumen merupakan dokumen yang digunakan untuk merekam terjadinya transaksi. Peraturan Pemerintah Republik Indonesia Nomor 24 Tahun 2005 menjelaskan sistem akuntansi pemerintahan adalah serangkaian prosedur manual maupun yang terkomputerisasi mulai dari pengumpulan data, pencatatan, pengikhtisaran dan pelaporan posisi keuangan dan operasi keuangan pemerintah.

Budaya yang dimiliki oleh setiap desa akan memberikan pengaruh terhadap praktek akuntansi suatu organisasi pemerintahan. Hal ini dikarenakan budaya itu sendiri akan terus ada dan mentradisi sehingga aka nada perbedaan yang mendasar tentang piha mana yang memiliki tanggungjawab untuk melaksanakan tugas dan wewenang untuk keberlangsungan kebudayaan atau kebiasaan adat istiadat yang ada serta tentang bagaimana proses pembukuan yang seharusnya dilakukan sesuai dengan cara yang dianggap sesuai dengan peraturan perundang-undangan yang berlaku dan dianggap dapat berterima umum bagi masyaakat pengguna laporan. Maka itu, terjadi pemisahan tugas dan wewenang dalam perangkat desa, pemisahan tersebut antara lainperangkat desa yang bertanggung jawab terhadap kependudukan (desa pakraman dinas) dengan sistem pencatatan akuntansi yang telah ditetapkan pemerintah pada umumnya dan perangkat desa yang bertanggungjawab terhadap adat istiadat (desa pakraman adat) dengan model pencatatan akuntansi yang berterima umum dalam masyarakat. Perangkat desa yang bertanggungjawab terhadap adat istiadat menurut UU No. 6 Tahun 2014 Tentang Desa, yaitu menempatkan Lembaga Adat sebagai lembaga yang menyelenggarakan fungsi adat istiadat dan menjadi bagian dari susunan asli desa yang tumbuh dan berkembang atas prakarsa masyarakat desa. Keberadaan lembaga adat di desa dalam hal ini tidak otomatis menyebabkan desa berubah status menjadi desa adat. Ketentuan khusus sebagaimana diatur dalam UU Desa menjelaskan bahwa desa adat harus memenuhi persyaratan sebagai kesatuan masyarakat hukum adat beserta hak tradisionalnya yang secara nyata masih hidup dengan ikatan territorial atau genelogis maupun fungsional. Sebagai kesatuan masyarakat hukum adat, desa adat memenuhi undur : (i) wilayah/ulayat adat, (ii) klompok warga masyarakat dengan ikatan perasaan bersama, (iii) memiliki pranata pemerintahan adat, (iv) memiliki kekayaan dan atau benda adat, (v) perangkat normal hukum adat beserta hak tradisionalnya masih berkembang dan sesuai dengan prinsip NKRI. Lembaga Adat Desa merupakan organisasi yang berkedudukan sebagai lembaga kemasyarakatan yang menjadi mitra Pemerintah Desa dalam memberdayakan, melestarikan, dan mengembangkan adat-istiadat lokal yang menunjang penyelenggaraan pemerintahan, kemasyarakatan dan pembangunan. Keberadaan Lembaga Adat Desa jug berfungsi mengayomi dan melestarikan nilai, system sosial maupun benda material dari kebudayaan local.

Berdasarkan pemaaan tersebut maka budaya lokal suatu desa akan memberikan pengaruh terhadap praktek akuntansi dari suatu organisasi pemerintah khususnya organisasi pemerintah desa. Akan ada pemisahan tugas dan wewenang suatu aparat/pemerintah desa untuk bertanggungjawab atas keberlangsungan praktek pencapaian tujuan desa dibidang kependudukan dan adat istiadat, yang disertai dengan perbedaan pencatatan akuntansi yang menyertai pemisahan tersebut dengan masih tetap merupakan tanggungjawab kepala desa selaku kepala pemerintahan tingkat desa. 


\subsection{Budaya Lokal Yang Dimiliki Desa Gobleg Serta Pencatatan Akuntansinya}

Dana yang dimiliki banjar adat asah, desa gobleg merupakan dana yang diperoleh melalui tradisi yang dijalankan. Berdasarkan hasil wawancara yang diperoleh, maka diketahui bahwa Desa Gobleg khususnya Banjar Adat Asah memiliki beberapa kebudayaan lokal yang berkembang dan mentradisi dalam hal pemasukan dan pengalokasian dana, yang diantaranya, yaitu :

A. Tradisi atau budaya dalam rangka perolehan dana tambahan desa pakraman

a) Punia Tukang Pajeg

Punia Tukang Pajeg merupakan tradisi yang dijalankan Banjar Adat Asah Desa Gobleg daam hal perolehan dana atas kepemilikan suatu kebun (pohon cengkeh, pohon jeruk dan lain sebagainya) tanpa memiliki surat tanah atas kebun tersebut. Tradisi ini terjadi musiman, yaitu ketika terjadi paneh atas hasil kebun yang menjadi hasil kebun masyarakat Desa Gobleg. Dana yang diperoleh dari tradisi ini, bukan merupakan pemasukan bagi Desa Gobleg, melainkan pemasukan bagi banjar adat beserta dengan jajarannya. Pencatatan yang dilakukan masih bersifat single entry atau sistem pembukuan tungga, dimana pencatatannya hanya dilakukan pada akun kasnya saja.

b) Punia Karma Tamiu

- Bagi Umat Hindu, punia krama tamiu meruakan tradisi yang dijalankan Banjar Adat Asah Desa Gobleg dalam hal perolehan dana dari mereka yang datang ke desa gobleg dalam rangka bekerja sebagai buruh hasil kebun musiman, buruh bangunan (proyek besar) dan buruh bangunan (proyek kecil) atas dasar yang telah ditetapkan

- Bagi Umat Non Hindu, tradisi yang dijalankan berupa pemungutan dana bulanan bagi mereka yang dianggap sebagai BOS, Buruh dan masyarakat non hindu yang berada di daerah desa gobleg.

Dana yang diperoleh dari tradisi ini sama halnya dengan dana yang diperoleh dari Tukang Pajeg, dimana dana yang diterima tidak secara langsung masuk ke dana kas desa, melainkan masuk ke kas banjar adat sebagai kas dalam rangka persiapan pelaksnaan prosesi adat. Sistem pencatatan yang dilakukan masih bersifat sederhana, yaitu menggunakan sistem single entry (pencatatan tunggal hanya pada penerimaan kas)

c) Penepak Kulkul Pelepas Karma Marabian, merupakan tradisi punia yang dijalankan Banjar Adat Asah, Desa Gobleg ketika terjadi pernikahan, dimana pengantin wanita berasal dari Desa Gobleg dan pengantin laki-laki berasal dari luar Desa Gobleg atau luar negeri. Dana yang diperoleh dari tradisi ini tidak sepenuhnya menjadi pengghasilan bagi banjar adat, karena bibagi menjadi dua post yaitu biaya transport untuk pelaksanaan perkawinan dan sisanya merupakan kas masuk bagi banjar adat. Disini biaya transport tidak dicatat sebagai pengeluaran yang sah, oleh karena itu pencatatan kas yang di dapat hanya pada post dana masuk setelah dikurangi biaya transport.

B. Tradisi atau Budaya Piodalan Prasasti

Tradisi atau budaya yang masih dijalankan oleh Banjar Adat Asah Desa Gobleg disetiap tahunnya yaitu salah satunya diadakannya upacara keagamaan besar yang disebut dengan "Karia 1 Lilitan Adat Dalem Tamblingan Banjar Pakraman Asah". Upacara ini dibagi menjadi 4 bagian, yaitu Karya Dalu (Upacara Pertama), Bongkol Karya (Upacara Dasar), Karya Pengerakihan, Madianing Karya dan Puncak Karya. Semua dana yang diperoleh dari tradisi yang dijalankan oleh tiap-tiap banjar adat di Desa Gobleg akan dipergunakan dalam rangka pelaksanaan upacara keagamaan yang mentradisi disetiap tahunnya. Pencatatan atas pengeluarannya dilakukan secara manual namun dengan sistem double entry (pembukuan berpasangan) dibuktikan adanya sisi debet dan sisi kredit pada laporan pertangungjawaban kegiatannya.

C. Tradisi Ngarap Uma

Tradisi Ngarap Uma atau tradisi menggarap ladang desa merupakan tradisi yang dulunya dilakukan di Desa Gobleg. Tradisi menggarap ladang ini dilakukan oleh kepala 
desa yang dijadikan sebagai imbalan atau gaji atas jabatannya sebagai kepala desa. Sebelum dikeluarkannya dana dari pemerintah untuk menggaji kepala desa, kepala desa hanya menerima pengghasilan dari pemanfaatan ladang yang diberikan oleh desa. Tradisi ini ini kemudian berubah seiring dengan pengaduan yang dilakukan oleh salah satu kepala desa yang melaporkan hak kepemilikan tanah desa kepada pemerintahan daerah atas ladang tersebut, yang mana tanah tersebut diakui oleh kepala desa merupakan tanah daerah namun kebenarannya tanah tersebut merupakan milik desa. Atas kejadian tersebut maka tanah tersebut kini dimiliki oleh pemerintah daerah dengan hasil dibagi dua setengah kepada pemerinth desa dan setengahnya kepada pemerintah daerah melalui kepala desa yang bersangkutan. Dana yang diperoleh atas kegiatan ini secara langsung menjadi pemasukan ke dana kas desa, dan pasti dana yang diperoleh ini digunakan sebagai dana pembangunan desa gobleg sendiri. Sehingga pencatatan atas penerimaan ini mengikuti pencatatan pemerintah desa sebagai pendapatan asli desa.

Dana yang diperoleh melalui tradisi yang telah dipaparkan tersebut semuanya akan dikelola oleh perangkat desa gobleg, khususnya banjar adat asah. Apabila terjadi kelebihan dana, maka dana tersebut bukan menjadi hak pemerintah dinas desa gobleg, melainkan tetap dijadikan sebagai kas banjar adat asah itu sendiri walaupun sebenarnya pemasukan dari tradisi tersebut merupakan bagian dari pendapatan asli desa.

\subsection{Pengaruh Budaya lokal desa gobleg terhadap praktek akuntansi organisasi pemerintahan perangkat desa.}

Berdasarkan pemaparan tersebut, terdapat pengaruh antara budaya local dengan praktek akuntansi organisasi pemerintah desa, dimana untuk menjalankan tugas dan fungsi dibidang adat istiadat, kepala desa memberikan wewenang kepada kepala desa pakraman adat untuk menghimpun dana, melakukan pencatatan atas perolehan dana, pengalokasian dana serta melakukan pelaporan atas penggunaan dana yang berhubungan budaya yang dimiliki sesuai dengan sistem pencatatan yang berterima umum dan mudah dipahami bagi masyarakat pengguna laporan sebagai bentuk pertanggungjawaban atas dana yang dihimpun melalui masyarakat. Berdasarkan hasil wawancara yang dilakukan, penghimpunan dana atas biaya yang dimiliki Desa Gobleg khususnya Banjar Asah dalam hal kewenangan perangkat desa dibidang adat istiadat dapat diketahui bahwa praktek akuntansi yang dilakukan masih sederhana yang dilakukan secara manual dilihat dari segi pembukuan penerimaan dana dan pengalokasian dana. Dana yang diperoleh dari budaya yang mentradisi dibukukan dengan sistem single entry, dimana hanya dilakukan pembukuan tunggal atas penerimaan kas melalui buku penerimaan kas, dan dalam hal pngalokasian dana dilakukan pencatatan dengan sistem berpasangan (double entry) dibuktikan dengan adanya sisi debet dan sisi kredit dalam laporan pertanggungjawaban kegiatan. Sebagai bagaian dari perangkat desa, perangkat desa yang memiliki wewenang dalam hal adat istiadat semestinya juga harus mengikuti sistem pencatatan yang telah ditetapkan yaitu, menggunakan sistem pencatatan ganda baik pada penerimaaan kas maupun pengeluaran kas, sehingga akan muncul laporan keuangan neraca yang menjadi laporan penting dalam setiap pencatatan akuntansi yang dilakukan.

\section{Simpulan dan Saran}

Dalam organisasi pemerintah Desa Gobleg, kepala desa membagi kewenangan perangkat desanya menjadi dua bagian, yaitu perangkat desa yang memiliki kewenangan dalam hal kepengurusan kependudukan (staf desa) dan perangkat desa yang memiliki kewenangan dalam hal adat dan istiadat (banjar adat), namun masih berada dibawah tanggung jawab kepala desa selaku kepala pemerinthan Desa Gobleg. Hal ini dikarenakan oleh adanya budaya yang dianut pemerintahan desa gobleg hingga saat ini. Hal itu juga akan memberikan pengaruh terhadap praktek akuntansi suatu organisasi pemerintahan, yang khususnya pada organisasi perangkat desa gobleg. Hal ini dikarenakan budaya itu sendiri akan terus ada dan mentradisi sehingga aka ada perbedaan yang mendasar tentang pihak mana yang memiliki tanggungjawab untuk melaksanakan tugas dan wewenang dibidang kependudukan dan keberlangsungan kebiasaan atau adat istiadat yang ada serta 
tentang bagaimana pembukuan yang seharusnya dilakukan sesuai dengan cara yang dianggap sesuai dengan Peraturan Perundang-Undangan dan kebiasaan umum yang dapat berterima umum dan mudah dipahami oleh pengguna laporan hasil proses akuntansi. Berdasarkan hasil wawancara yang dilakukan, penghimpunan dana atas budaya yang dimiliki desa gobleg khususnya banjar asah dalam hal kewenangan perangkat desa dibidang adat istiadat dapat diketahui bahwa praktek akuntansi yang dilakukan masih sederhana yang dilakukan secara manual dilihat dari segi pembukuan penerimaan dana dan pengalokasian dana. Dana yang diperoleh dari budaya yang mentradisi dibukukan dengan single entry dimana hanya dilakukan pembukuan tunggal atas penerimaan kas melalui buku penerimaan kas, dan dalam hal pengalokasian dana dilakukan pencatatan dengan system berpasangan (double entry) dibuktikan dengan adanya sisi debet dan sisi kredit dalam laporan pertanggungjawaban kegiatan. Sebagai bagian dari perangkat desa, perangkat desa yang memiliki wewenang dalam hal adat istiadat semestinya juga harus mengikuti system pencatatan yang telah ditetapkan yaitu menggunakan system pencatatan ganda baik pada penerimaan kas maupun pada pengeluaran kas, sehingga akan muncul laporan neraca yang menjadi laporan penting dalam setiap pencatatan akuntansi yang dilakukan.

Berdasarkan hasil penelitian dalam bentuk wawancara yang telah penulis lakukan, adapun saran yang dapat kami sampaikan, yaitu: kebudayaan memang harus dilestarikan sebagai ciri khas bagi suatu desa, namun sebagi bagian dari organisasi pemerintahan, sudah seharusnya semua perangkat desa menerapkan praktek akuntansi yang tengah gencar diterapkan oleh pemerintah tentang pengelolaan keuangan negara. Meskipun tidak semua aparat perangkat desa, merupakan lulusan akuntansi penulis menghimbau bagi pemerintah desa gobleg setidaknya harus memberikan pelatihan dan pengajaran kepada para aparat desanya untuk dapat melakukan proses pencatatan sesuai dengan peraturan yang ada, namun masih berterima umum bagi masyarakat desanya. Tidak hanya itu, pemerintah desa juga harus dapat mempublikasikan hasil penggunaan dana yang dimiliki kepada masyarakat sehingga masyarakat tahu kineja pemerintah, khususnya para aparat desanya.

\section{DAFTAR PUSTAKA}

Badan Pemberdayaan Masyarakat. 2015. Pelestarian dan Pengembangan Adat Istiadat dan Nilai Sosial Budaya Masyarakat. Jatim : Bidang Sosbud Bapemas. http://artikelaz.com/pengertian-budaya-lokal/[Diakses 3 Januari 2017]

http://id.wikipedia.org/wiki/Budaya[Diakses 3 Januari 2017]

Ikatan Akuntansi Indonesia. 2015. Pedoman Asistensi Keuangan Desa. Jakarta: Devisi Penerbit IAI

Satria. 2016. Sistem Pemerintahan Desa di Negara Indonesia. http://www.materibelajar.id/2016/03/sistem-pemerintahan-desa-dinegara.html[Diakses 3 Januari 2017] 